\title{
The Impact of Domestic and External Public Debt on the Economic Growth of Jordan
}

\author{
Eman Abdel Khalek Fseifes ${ }^{1,}$, , Talib Mohammad Warrad ${ }^{2}$ \\ ${ }^{1}$ Department of Business Economics, School of Graduate Studies, University of Jordan, Amman, Jordan \\ ${ }^{2}$ Department of Business Economics, School of Business, University of Jordan, Amman, Jordan
}

Email address:

iman.fseifes@gmail.com (E. A. K. Fseifes), talibawad@yahoo.com (T. M. Warrad)

${ }^{*}$ Corresponding author

\section{To cite this article:}

Eman Abdel Khalek Fseifes, Talib Mohammad Warrad. The Impact of Domestic and External Public Debt on the Economic Growth of Jordan. International Journal of Business and Economics Research. Vol. 9, No. 4, 2020, pp. 254-262. doi: 10.11648/j.ijber.20200904.22

Received: July 16, 2020; Accepted: July 29, 2020; Published: August 10, 2020

\begin{abstract}
Since the beginning of the new millennium several developing countries have been making greater use of domestic bond markets, with a corresponding decline in gross and net foreign debt-to-GDP ratios. Jordan was not an exception; the structure of the public debt in Jordan has exhibited a similar shift towards the domestic borrowings after the year 2000. In order to assess the economic consequences of this change in the public debt structure, this study investigates the impact of the structure of the public debt and other determinants of growth on the economic growth in Jordan over the period 1980 - 2018. The analysis of the long-run relationship between the domestic and external public debt and the economic growth is reliant on the theoretical assumptions and the empirical concerns and it is conducted by applying the Fully Modified Ordinary Least Squares (FMOLS) method; the results indicate that the external and domestic public borrowings are negatively associated with economic growth with a greater magnitude of the domestic debt in the long-run; the greater magnitude of the negative implication of domestic debt on economic growth is attributed to the increased trend of domestic debt that has been increasing in excess of the external debt since 2008. On the other hand, investment, labor force growth, and openness of trade are found to be positively associated with economic growth in the long-run. Accordingly, this study recommends the need to reduce the public debt and budget deficit to moderate levels in the long-run through implementing austerity measures and fiscal discipline that are carefully planned to minimize the potential negative effect on economic growth, where they should be implemented along with fiscal reforms intended for increasing employment and boosting Jordan's growth potential. It is also recommended that the government should thoroughly revise the debt management strategy, so as to avoid the deterring effects of the increased stock of domestic debt on capital accumulation and economic growth in the long-run.
\end{abstract}

Keywords: Co-integration, Domestic Debt, Economic Growth, External Debt, FMOLS

\section{Introduction}

After the accumulation of a substantial burden of public debt and its servicing in Jordan recently, the financial distress of the public sector has become a major concern for the Jordanians, which has put a pressure on the Jordanian government to restructure its debt, privatize and improve tax revenues collection [1].

In addition to the adverse effects of financial crisis of 2008-09, the economic growth in Jordan was adversely influenced by a series of external shocks that followed the break of the Arab uprisings in 2011, including, but not limited to, the massive influx of Syrian refugees after 2012, the interruptions of Egyptian gas supplies to Jordan during 2013-2014, that forced the Jordanian government to switch to very costly alternative energy sources, and the trade route closures due to increased insecurity in neighboring countries of Syria and Iraq in 2015; these external shocks have been exaggerated by the long-lasting structural weaknesses of the economy, including high chronic fiscal deficit and high unemployment rate [1]. Since then and until now, the average annual growth rates has declined to around $2.6 \%$. Furthermore, Jordan's total public debt has increased at a rate surpassing the rate of economic growth, which has currently reached above $94.4 \%$ of GDP as indicated by the Central 
Bank of Jordan report in 2018.

This level of public debt requires a careful debt management to be adopted by the government in order to decrease the negative effects of the accumulated burden of public debt and its servicing on the Jordanian economy in the long-run, since that the channels of impact through which public debt might deter the long-term economic growth are various. The economic literatures emphasized the role of the increased distortionary taxation in decreasing the future physical capital accumulation; also the increased long-term interest rates would slow down physical capital accumulation through crowding out private investments. The literature also emphasized the role of high inflation especially in lowincome counties, where the governments in these countries used to monetize their debt that has serious negative implication on growth [2].

However, the effect of public debt on economic growth is a debated topic in the economic theory [3]. There are many cyclical and structural elements that have contributed to the uncertain results on the relationship between public debt and economic growth. Many scholars argued that governments with high levels of debt have limited capacity on conducting countercyclical policies and as a result, the volatility of output is increased and economic growth is depressed $[4 ; 5]$. Nevertheless, the relationship between public debt and the ability of conducting countercyclical policies is expected to be dependent on the composition of public debt rather than on the level of public debt $[6 ; 7]$. This conclusion has shed the light on the importance of the public debt structure and indicated that countries with diverse monetary arrangements and debt structures seem to start facing difficulties at very different levels of public debt.

Public debt can be categorized based on the residence of the creditor as external and domestic debt. The former is debt owed to non-residents, which is accumulated through borrowing from international financial institutions and selling government issued securities to foreigners. The latter is debt owed to residents, which is accumulated through selling government issued securities within the country to domestic financial institutions, such as private local banks and domestic investors. In their attempt to finance budget deficits, governments are faced with the choice between external and domestic borrowing. If choices are accessible, then the choice summarizes to cost versus risk [8].

Nevertheless, the first choice is the reception of conditional loans that requires compromises on a country's national independence that would result in critical political and economic conditions. While the second choice is to borrow domestically and entering on the demand side of the capital market along with the private investors that would increase the cost of capital and crowd out private capital formation.

This study focuses on the dynamic relationship between the structure of the public debt and economic growth in Jordan, by applying a Fully Modified Ordinary Least Squares (FMOLS) approach adopted to test the long-run relationships between the variables on time series data over the period $1980-2018$.
This study is motivated by the alternating patterns of Jordan's public debt observed during 1980-2018; the magnitude of the components of Jordanian public debt has changed during the study's period; since its constitution and until 2000, Jordan had been heavily reliant on external borrowings that represented the larger component of its public debt. However, during 2000-2008, the magnitude of the domestic borrowings has gradually increased. Since then and until now, the domestic public debt has become the larger component of the Jordanian public debt. Not surprisingly, many studies showed that since the beginning of the new millennium several developing countries have been making greater use of domestic bond markets, with a corresponding decline in gross and net foreign debt-to-GDP ratios. They also show that emerging market countries with lower levels of foreign currency debt are better able to conduct countercyclical macroeconomic policies [6]. However, the modern change in the debt structure towards domestic borrowings leads to changing the source of vulnerability rather than eliminating it. For example, countries that are changing their debt structure from external to domestic borrowings might be replacing a currency mismatch by a maturity mismatch. On the other hand, the change towards domestic borrowings could adversely affect the financial stability of the country through the burden placed on the local financial and banking institutions to finance the increased sovereign debt [8].

The remainder of this study is organized as follows: Section 2 provides an overview of the external and domestic public debt developments in Jordan. Section 3 includes the study's theoretical and empirical literature on the relationship between the structure of the public debt and economic growth. Section 4 describes data and provides an overview of the empirical model applied. In Section 5 the study's results are presented. Section 6 concludes by the policy implications.

\section{An Overview of the External and Domestic Public Debt Developments in Jordan}

Jordan is endowed with limited resources, and as a result, it suffers from prolonged budget deficit, which is usually monetized by government debt. Jordan has a long history of public debt, as it had been greatly reliant on external borrowings since its constitution; official public debt records indicate that the first external loan had been granted to Jordan by the British government in the fiscal year 1949-1950 [9]. For long years, Jordan has resorted to the World Bank to finance its investment projects; this tradition was enlarged in the 1980s. Jordan also relies heavily on the external financial aid, which is usually granted to Jordan in the form of official development assistance, grants for particular projects, and conditional and non-conditional loans [10].

Since its constitution, Jordan has been heavily reliant on external financing sources that usually take the form of foreign conditional loans and grants. Thus, until the year 
2000, the majority of kingdom's public debt in relation to GDP was external. However, after 2000, the Jordanian government has increased the domestic public debt component in an attempt to diversify its public debt [10].

During 1980-1987, Jordan's outstanding external public debt to GDP ratio averaged 46.3 percent compared with 18.7 percent for outstanding domestic public debt to GDP ratio, indicating that the Jordanian government had traditionally emphasized the external indebtedness. However, in 1989, both components of public debt have reached a peak at 223 percent and 41 percent for external and domestic public debt to GDP ratio, respectively, which was attributed to the financial crisis of 1988-1989.

Since then the external public debt showed a favorable downward trend over the period 1990-2008, which was largely attributed to the increased financial assistance to Jordan along with debt write-offs and rescheduling arrangements, while the domestic public debt to GDP ratio showed a moderate downward trend with an average of 26 percent during 19901999, which was largely attributed to the increased financial assistance to Jordan. Then the domestic public debt to GDP ratio showed a steady upward trend with an average of 27 percent during 2000-2008, indicating the increased magnitude of domestic debt over time.

Since 2008 and until now, the domestic public debt has become the larger component of the Jordanian public debt, which is largely attributed to the increased proportion of government guaranteed debt that includes the loans and bonds issued to cover the generated losses of own budget agencies, such as The National Electric Power Company (NEPCO) and The Water Authority of Jordan (WAJ). However, Jordan's medium-term debt management strategy has emphasized the external borrowings as a source of financing the needs of the central government during 20162020, as indicated by the Ministry of Finance report in 2018.

In 2018, the domestic debt reached JD billion 16.22 (54.1\% of GDP) while the external debt reached JD billion 12.08 (40.3\% of GDP). The majority of the domestic public debt is borrowed from the private banking sector; in 2018, claims on the public sector by domestic banks reached JD million 9,824.1, that are equivalent to $60.6 \%$ of domestic debt for the same year as indicated by the Central Bank of Jordan report in 2018.

Figure 1 compares between the trends of external and domestic public debt in Jordan as share of GDP over the period 1980- 2018.

Figure 1 demonstrates the changed magnitudes of public debt components in Jordan after 2000, where the external public debt showed a favorable downward trend that coincided with an unfavorable upward trend of the domestic debt during 2000-2008. However, after 2008, the domestic debt has exceeded the external debt. Figure 1 also presents the negatively sloped linear trend for Jordan's external public debt, indicating that the external public debt to GDP ratios have a tendency to decline over time; along with the slightly positively sloped linear trend for Jordan's domestic public debt, indicating that the domestic public debt to GDP ratios have a tendency to increase over time.

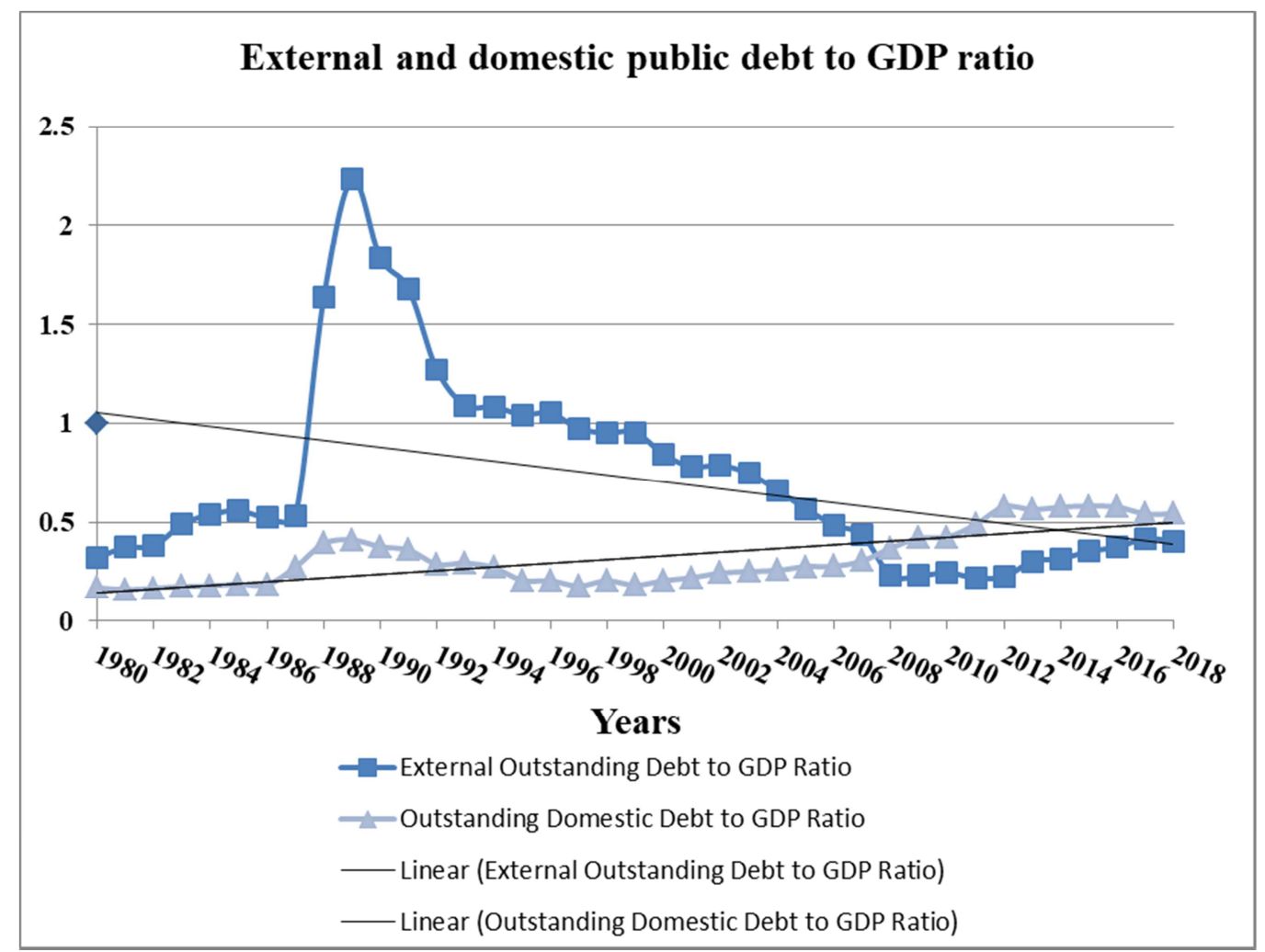

Source: Drawn by the researcher based on Central Bank of Jordan Database

Figure 1. External versus domestic public debt in Jordan as share of GDP over the period 1980-2018. 


\section{Literature Review}

This study reviews the theoretical literature and the empirical literature on the association between the public debt structure and economic growth.

\subsection{The Theoretical Literature}

Many economists argued that the composition of public debt has a causal effect on economic growth. Particularly, after the Asian financial crisis that negatively influenced several emerging economies in the second half of the 1990s, the debate has been intensified on the perceived impact of debt composition and currency denomination on economic growth. As a matter of fact, the common feature among the considered crisis countries is the presence of huge liabilities denominated in foreign currencies; this evidence caused the majority of economists to conclude that the currency denomination of the public debt could magnify the impact of financial crises. Nevertheless, other economists argued that public debt currency denomination reveals the failure of domestic policies and institutions and as a result, the financial crises are attributed to these failed policies and institutions $[11 ; 12]$.

Thus, the theoretical literatures have emphasized the deterring effect of external debt on economic growth and the conditions under which such effect is triggered. The major topic addressed by the theoretical literature on the relationship between the external debt and economic growth was the deterring effect of debt overhang which is defined as a condition in which the expected repayment on external debt falls short of the contractual value of debt. If there is a future probability that the debt level in a country might surpass that country's repayment capacity, the projected debt service would become an increasing function of the output level of that country. Hence, a part of the returns generated from domestic investments are effectively swiped by taxes to the benefit of foreign creditors that would deter both the domestic and foreign investments and as a result, economic growth is depressed. Debt overhang also discourages investments and economic growth through increased uncertainty. Particularly, the expectations about the distortionary procedures that the government might adopt to finance its debt service obligations resulting from the increased public debt. For example, the increased taxation with deterring impact on investment $[13 ; 14]$.

External public debt is normally denominated in foreign currency that might limit the country's capacity of implementing monetary policies and managing exchange rate. Exchange rate is another channel through which the external public debt could depress economic growth. It has been argued that external borrowings provide the country with foreign exchange, which might create an appreciation in exchange rate. Thus, decreasing the country's trade competitiveness and probably depressing aggregate demand, investment and economic growth [15].

The mainstream of public debt literature in developing countries has been conventionally concentrated on external debt. However, since the mid-1990s, domestic public debt started to increase accompanied with increased financial liberalization [16]; several developing countries retired their external public debt through substituting it for domestically supplied public debt $[8 ; 6]$. In fact, the policy makers are attempting to optimize the composition of public debt. Nevertheless, the switch to domestic public debt necessitates essential trade-offs in terms of costs and risks. The policy makers should be worried that on the one hand, the change in the direction of more domestically issued public debt might reduce the risks of sovereign finance; on the other hand new vulnerabilities are anticipated as a result of the new debt composition [8].

The theoretical literature emphasized that the accumulation of domestic public debt exerts a significant negative effect on private sector investments, fiscal sustainability, economic growth, and poverty reduction. As a result, the theoretical literature has conventionally advised the limitation of domestic public debt accumulation [17].

Thus, the major concern about the accumulation of domestic public debt is the crowding out effect on private sector investments. When a government borrows domestically, it consumes the private savings that would limit the funds available to lend private sector. In sequence, the limited available loanable funds in the domestic market would increase the cost of capital on the borrowings of private sector and as a result, decreasing the demand of private investment and thus depressing capital accumulation, economic growth, and welfare. In narrow financial markets, particularly where businesses are restricted from accessing international financing sources, domestic public debt accumulation could significantly crowd out private sector lending [17].

The theoretical literature on domestic public debt is also concerned with the potential effects on fiscal and debt sustainability. The domestic public debt tends to be more costly than the concessionary external borrowing [8]. Thus, the debt service or interest burden of domestic public debt might consume a substantial portion of governmental revenues that would decrease the provision for growth stimulating spending. In other words, the limited accumulation of the expensive domestic borrowing is perceived to be beneficial for economic growth in developing countries [17].

However, domestic borrowings would reduce the country's vulnerability to the external and domestic monetary shocks through implementing countercyclical monetary policy [18]; moderate the risks of sovereign finance through the lowered exposure to currency risk provided that the denomination of domestic public debt is in the local currency [19]; and decrease the dependency on foreign reliefs. The previous arguments in favor of domestic public debt are practically verified by the experience of the fast growing emerging countries, such as China, India, and Chile, as they have accumulated very limited stock of external public debt, and 
thus avoided serious financial crises [17].

Many economists argued that the long-term domestic public debt being denominated in the local currency is safer than external debt, since that the maturity and currency mismatches are avoided. Nevertheless, they emphasized that the potential benefits of domestic public debt are realized in the presence of a matured financial and macroeconomic structure and provided that the debt is structured with prescribed cautious considerations $[8 ; 16 ; 17]$.

\subsection{The Empirical Literature}

The empirical literature on the role of external debt in developing countries was emerged in the 1980s as a result of the argument on the debt relief programs, in addition to the absence of dependable data on domestic public debt for many countries, which represents approximately two-third of public debt $[20 ; 21]$.

An empirical study analyzed the time series data for Kenya over the period 1970-1995, the empirical results indicated that external debt accumulation has a negative impact on economic growth and private investment. This confirms the existence of a debt overhang problem in Kenya [22].

Another empirical study analyzed a panel data of 59 developing countries over the period 1970-2002; the study found an evidence of a negative effect of external debt on per capita income growth rate [23].

In a study of "External Debt Sustainability: Theory and Evidence," it was found that large external debt stocks lead to capital flight, higher tax rates and continuous over-borrowing and therefore impacts negatively on economic growth [24].

However, the domestic public debt is not a new phenomenon for developing countries. However, continues to be a debatable subject among scholars and policy-makers [17].

An empirical study analyzed the optimal domestic debt level in low-income countries (including 40 sub Saharan African countries) and emerging markets between 1975 and 2004 found out that moderate level of marketable domestic debt as a percentage GDP have significant positive effect on economic growth. The study also provided evidence that debt levels exceeding 35 percent of total bank deposits have negative impact on economic growth [17].

Another empirical study examined the effect of domestic debt on the Nigerian economy during the period 1986-2005 using OLS technique. The findings revealed that domestic debt has negatively affected the growth of the economy and recommends that the government should introduce efforts to resolve the outstanding domestic debt [25].

Another empirical study investigated the impact of external debt and domestic debt on economic growth in Nigeria during 1970 - 2010, the results revealed that external debt possessed a negative impact on economic growth while domestic debt has positively impacted the economic growth. They opined that government should rely more on domestic debt in stimulating growth rather than external debt [26].

Al-Adayleh, et al. [9] investigated the structure of public debt in Jordan and its effect on economic growth during 1980-2012. They applied a Fully modified least squares
(FMOLS) approach in order to measure the impact of internal and external public debt on economic growth; they found that the external public debt has a negative influence, while the domestic public debt has a positive influence on economic growth. Moreover, the study recommended that the external debt must be utilized in financing productive investments so as to minimize the burden of debt service liability.

Alshyab [10] investigated the economic growth consequences of public debt in Jordan during 1980-2013, disaggregating the effect of public debt to its external and domestic components. The empirical analysis has relied on a neoclassical growth framework of Cobb-Douglas production function extended with a public debt indicator in addition to the capital and labor as independent factors of production. The study applied a Johansen cointegration approach along with Vector Error Correction Model in order to measure the long-run relationships between the total public debt, external debt, domestic debt and the economic growth. The study found evidence for a negative impact of public debt on economic growth. Moreover, the negative contribution of domestic debt is of a similar magnitude to the negative contribution of external debt to the economic growth.

\section{Methodology}

\subsection{The Study Sample and Variables Description}

The empirical analysis is constructed on annual data on Jordan covering the period 1980-2018, accumulating thus of 39 data observations of each variable considered. The data are obtained from the Central Bank of Jordan (CBJ) yearly statistical series and World Bank- World Development Indicators (WDI).

Real GDP growth rate (annual \%) (YG): The annual growth rate of real gross domestic product (at basic prices) based on constant local currency, indexed at 1994-GDP deflator. As a proxy for economic growth, it is defined as the annual percentage change in real GDP.

Gross fixed capital formation growth rate (annual \%) (GFCF): Average annual growth of gross fixed capital formation based on constant local currency. As a proxy for the annual percentage change in fixed capital accumulation for a given country that consists of outlays on additions to the fixed assets of the economy plus net changes in the level of inventories.

Total labor force growth rate (annual \%) (LG): Annual labor force growth rate, Labor force or currently active population, includes people ages 15 and older who supply labor for the production of goods and services during a specified period. It includes people who are currently employed and people who are unemployed but actively seeking work in addition to first-time job-seekers.

Openness of Trade (\% of GDP) (OT): Trade is the sum of exports and imports of goods and services measured as a share of gross domestic product. As a proxy of economic policies that either constrain or promote trade among 
countries, the higher the index the larger the effect of trade on economic activities within the country's economy.

External public debt (\% of GDP) (ED): The outstanding external public debt to GDP ratio is the outstanding external public debt measured as a share of gross domestic product.

Domestic public debt (\% of GDP) (DD): The outstanding domestic public debt to GDP ratio is the outstanding domestic public debt measured as a share of gross domestic product.

\subsection{The Criteria for Selecting the Explanatory Variables}

This study adopts a neoclassical growth framework to empirically investigate the effect of the structure of public debt to GDP ratio and other determinants of economic growth including investment, labor force, and trade openness on economic growth in Jordan. The reason for selecting this set of growth determinants is related to their positive and significant contribution to economic growth, where the gross fixed capital formation and labor force growth rate reflect the positive impact of physical and human capital accumulation on economic growth. Economic theory suggests that higher rates of savings and investments are main determinants of the longrun economic growth, as the increased rates of investments and savings result in increased accumulated capital per worker that would increase economic growth at a decreasing rate. Furthermore, the endogenous growth models emphasized the importance of human capital accumulation as an endogenous source of technology and economic growth. Trade openness is also suggested to enhance productivity through transfer of knowledge and increased efficiency [27;28].

Several previous studies demonstrated that the aftermath of a deep financial crisis usually involves prolonged period of macroeconomic adjustment, mainly in employment and accommodation prices. The average increase in public debt has exceeded 80 percent within three years after the global financial crisis. However, it increased at an average of around 20 percent in real terms in the countries that did not experience a deep financial crisis during 2007-2009, as revealed in the previous studies, such as [29; 30]. Such findings necessitate consideration of the financial crises that had been occurred during the study's period by inclusion in crisis dummy variables to the study's models. Thus the study will account for the negative impact of the two financial crises on real output growth rate over the study's period, where two dummy variables are included as additional independent variables to estimate the effects of Jordan's financial crisis of 1989-1990 and the global financial crisis of 2008-2009, the study uses the 2-year definition of crises that consists of two observations for each crisis, the crisis dummy variable takes a value of one if the observation occurs during a financial crisis and zero otherwise.

\subsection{The Empirical Model}

The study's econometric approach is relied on an augmented Solow growth model, extended by a debt variable. Following the modeling approach of previous studies, such as $[31 ; 32]$; our specification assumes that the economic growth for a country follows a linear relationship over a period $\mathrm{t}$ :

$$
y g_{t}=\alpha+\beta T D_{t}+\delta X_{t}+\varepsilon_{t}
$$

Where yg is annual real GDP growth rate, TD is the outstanding gross total public debt to GDP ratio, and $\mathrm{X}$ is a vector of Solow explanatory variables including gross fixed capital formation (gfcf), labor force growth rate (lg), and openness of trade (ot).

Pursuing the econometric approach applied in the previous empirical studies that investigated the growth implications of public debt by disaggregating the total public debt into its external and domestic components, so as to measure the impact of external and domestic public debt on economic growth separately, such as $[9 ; 26]$.

Rewriting equation (1) to measure the impact of external and domestic public debt on economic growth, we get:

$$
\begin{gathered}
y g_{t}=\beta_{0}+\beta_{1} E D_{t}+\beta_{2} D D_{t}+\beta_{3} g f c f_{t}+\beta_{4} l g_{t}+\beta_{5} o t_{t}+ \\
\beta_{6} D 1989+\beta_{7} D 2008+\varepsilon_{t}
\end{gathered}
$$

Where yg is the annual growth rate of real gross domestic product (GDP); ED is the outstanding gross external public debt to GDP ratio; DD is the outstanding gross domestic public debt to GDP ratio; (GFCF) is the gross fixed capital formation, (LG) is the labor force growth rate; (OT) is the openness of trade; D1989 is a dummy variable to measure the impact of Jordan's financial crisis of 1989; and D2008 is a dummy variable to measure the impact of the global financial crisis of 2008.

$\beta 0$ denotes the constant term, $(\beta 1, \beta 2, \beta 3, \beta 4, \beta 5, \beta 6, \beta 7)$ are coefficients to be estimated, $\mathrm{t}$ denotes the year, and $\varepsilon$ denotes the random error term. The coefficients of the public debt variables are almost always negative and statistically significant; however, the coefficients of the other growth determinants variables are usually positive and statistically significant, as implied by the previous empirical studies.

\subsection{The Empirical Results}

The most important part of the time series analysis is selecting the proper methodology for estimating the time series data, as applying inappropriate method yields biased and unreliable estimations of the variables, thus it is important to comprehend the behavior of the variables, their connections and integrations over time; particularly, the stationarity of the time series.

The method selected to analyze the time series data is reliant on the unit root test outcomes, which define the stationarity of each variable in terms of the order of integration denoted by $I(d)$, which reports the minimum number of differences required to obtain a stationary series. Since that the econometric approaches applied to examine the stationary time series cannot be applied to non-stationary time series [33]. Thus, the analysis starts with exploring the properties of time series; the conventional unit root test is carried out in the next section. 


\subsubsection{Unit Root Test Results}

The unit root test on the series of real GDP growth rate $(\mathrm{YG})$, gross fixed capital formation growth rate (GFCF), labor force growth rate (LG), openness of trade (OT), external public debt (ED), and domestic public debt (DD) are carried out separately at level data and at first difference, including both trend and intercept by using the commonly used unit root test method the Augmented Dickey-Fuller (ADF), The results are presented below in Table 1.

Table 1. Augmented Dickey-Fuller (ADF) unit root test result.

\begin{tabular}{llllll}
\hline \multirow{2}{*}{ Variable } & Level & \multicolumn{3}{c}{ First difference } & \multirow{2}{*}{ Results } \\
\cline { 2 - 5 } & t-stat & p-value & t-stat & p-value & \\
\hline YG & -4.32 & 0.0077 & -9.41 & 0.0000 & $\mathrm{I}(0)$ \\
GFCF & -5.12 & 0.0009 & -6.80 & 0.0000 & $\mathrm{I}(0)$ \\
LG & -5.13 & 0.0009 & -5.52 & 0.0004 & $\mathrm{I}(0)$ \\
OT & -2.04 & 0.5611 & -5.05 & 0.0011 & $\mathrm{I}(1)$ \\
ED & -2.63 & 0.268 & -3.70 & 0.036 & $\mathrm{I}(1)$ \\
DD & -1.20 & 0.896 & -3.97 & 0.018 & $\mathrm{I}(1)$ \\
\hline
\end{tabular}

As shown in Table 1, the results of augmented DickeyFuller (ADF) tests for stationarity show that the series of real GDP growth rate (YG), gross fixed capital formation growth rate (GFCF), and labor force growth rate (LG) are stationary at the level data $\mathrm{I}(0)$. However, the series of openness of trade (OT), external public debt (ED), and domestic public debt (DD) become stationary at first difference I(1).

\subsubsection{Co-integration Tests Results}

If two or more series are found to be non-stationary processes, then a cointegration test should be applied to examine the relationships among the non-stationary variables, whether they are having an equilibrium relationship over the long-run or not. In other words, if two or more series are found to be non-stationary, but a linear combination of them is stationary, then they are assumed to be cointegrated [34].

Based on the results of the unit root test introduced in the previous section, The variables are found to be of mixed nature, i.e., some are stationary $\mathrm{I}(0)$ and others are nonstationary but integrated of first order I(1); thus the cointegration of the variables should be examined to verify the existence of an equilibrium relationship over the long-run among the variables considered. The Engle- Granger cointegration test is applied to the considered variables; the obtained results are presented in Table 2.

Table 2. Engle- Granger cointegration test result.

\begin{tabular}{lll}
\hline & Value & Probability \\
\hline Engle-Granger tau-statistic & -6.813 & 0.0079 \\
Engle-Granger z-statistic & -42.36 & 0.0068 \\
\hline
\end{tabular}

As introduced in Table 2, the null hypothesis of the EngleGranger cointegration test is rejected, at a significance level of $1 \%$; thus the considered variables are cointegrated. Thus there is a long- run relationship among the variables.

\subsubsection{The Specified Model Estimation Results}

Based on the outcomes of the unit root and cointegration tests, the appropriate method of estimation would be selected and applied to estimate the econometric model [33]. There exists a long-term or equilibrium relationship among the variables considered, thus the study will use Fully Modified Ordinary Least Squares (FMOLS) to estimate the prescribed econometric model targeting improved estimation along with enhanced conventional test statistics used for inference. The method of FMOLS estimator proposed by Philips and Hansen [35] is applied to examine dynamic interactions when the variables are cointegrated in order to obtain optimum estimations. The method adjusts least squares to address both the potential serial correlation in the residual and the endogeneity of the independent variables that are attributed to the cointegrating relationship [36]. The equation (2) has been estimated and the obtained results are showed in Table 3.

Table 3. Estimated long-run coefficients using the FMOLS approach.

\begin{tabular}{llll}
\hline \multicolumn{3}{l}{ Dependent Variable: YG } & \\
\hline Variable & Coefficient & t-Statistic & Prob. \\
\hline GFCF & 0.001272 & 5.822843 & 0.0000 \\
LG & 0.197997 & 2.473407 & 0.0193 \\
OT & 0.000605 & 2.766652 & 0.0096 \\
ED & -0.033365 & -3.429805 & 0.0018 \\
DD & -0.059196 & -2.246755 & 0.0322 \\
D1989 & -0.091898 & -4.0661 & 0.0003 \\
D2008 & -0.036746 & -2.374605 & 0.0242 \\
Constant & 0.005937 & 0.196015 & 0.8459 \\
R-squared & 0.714504 & & \\
\hline
\end{tabular}

The estimation results indicate that all the signs of the coefficients are in line with the economic theory, as shown in Table 3. Both external debt and domestic debt are having negative implications for economic growth with negative and statistically significant coefficients in the long-run. However, the domestic debt is having the greater magnitude; where a $1 \%$ increase in the domestic public debt to GDP ratio causes the real GDP growth rate to decrease by approximately $0.059 \%$ at a significance level of $5 \%$; while a $1 \%$ increase in the external public debt to GDP ratio causes the real GDP growth rate to decrease by approximately $0.033 \%$ at a significance level of $1 \%$, which is consistent with the economic literature.

The labor force growth rate (LG) has the highest coefficient of 0.19 and it is statistically significant at the $5 \%$ level, which implies that the real growth rate (YG) is highly effected by the labor force growth rate in the long-run, where a $1 \%$ increase in labor force growth rate causes the real GDP growth rate to increase by about $0.19 \%$. However, the openness of trade (OT) has the lowest coefficient of 0.0006 and it is statistically significant at the $1 \%$ level, which implies that the openness of trade has a little impact on the real GDP growth rate in the long-run, where a $1 \%$ increase in openness of trade causes the real growth rate to increase by approximately $0.0006 \%$, which is an immaterial contribution to growth. The gross fixed capital formation (GFCF) is also found to have a significantly positive long-run relationship with the real GDP growth rate, where a $1 \%$ increase in the gross fixed capital formation growth rate causes the real GDP growth rate to increase by approximately $0.0013 \%$ at a 
significance level of $1 \%$.

The global financial crisis (D2008) has exerted a significant negative impact on the real GDP growth rate by $0.036 \%$ at a significance level of 5\%. However, the greatest negative impact on the real GDP growth rate is attributed to the twin currency and financial crisis of 1989 (D1989) that has exerted a significant negative impact on the real GDP growth rate by $0.092 \%$ at a significance level of $1 \%$, which is consistent with the economic literature. The coefficient of determination $\left(\mathrm{R}^{2}\right)$ indicates that 71 percent of the variation in real GDP growth rate is explained by the specified model.

\section{Conclusion}

Given the persistent increase of public debt figures in Jordan in the recent years, this study attempts to widen the scope of the previous studies by analyzing the impact of the structure of public debt on economic growth in a dynamic framework. The analytical purpose is on identifying the dynamic impact of the structure of public debt and other selected growth determinants on economic growth in Jordan with inclusion of the data of the latest years.

In the direction of this purpose, this study investigates the relationship between external and domestic debt and economic growth within a standard neoclassical growth framework, extended by a public debt indicator. The econometric model is estimated by using the Fully Modified OLS (FMOLS) method, which is an appropriate technique to examine the dynamic interactions and the long-run equilibrium when the variables considered in the model are non-stationary and it also takes into account the possible endogeneity among the variables.

Reliant on the empirical analysis of the relationship between the structure of public debt and economic growth in Jordan during 1980-2018, the study suggests that the external and domestic public borrowings have negative implications on growth with a greater magnitude of the domestic debt. On average, a $1 \%$ increase in the external debt-to-GDP ratio is associated with a slowdown in real GDP growth rate of $0.033 \%$ in the long-run. While a $1 \%$ increase in the domestic debt-to-GDP ratio is associated with a slowdown in real GDP growth rate of $0.059 \%$ in the long-run.

The greater magnitude of the negative implication of domestic debt on economic growth is attributed to the increased trend of domestic debt that has been increasing in excess of the external debt since 2008. This result is consistent with the findings of the previous studies that aimed at estimating the impact of the public debt components on economic growth in Jordan. Al-Adayleh, et al. [9] investigated the structure of public debt in Jordan and its impact on economic growth during 1980-2012. They found that the external debt has a negative impact, while domestic debt has a positive impact on economic growth. However, Alshyab [10] investigated the growth implications of public debt in Jordan by investigating the long-run relationship between external and domestic debt variables and economic growth during 1980-2013. The study found that the negative contribution of domestic debt to economic growth seems to be of similar magnitude as the contribution of the external debt. In contrast, this study that includes the latest years up to 2018, finds a greater magnitude of the negative impact of domestic debt on economic growth, not surprisingly, this chronological change in the impact of domestic debt in economic growth is attributed to the increased trend of domestic debt that has been increasing in excess of the external debt since 2008, which justifies the increased negative implications of the domestic debt on economic growth over the time as revealed by the previous studies.

\section{Policy Implications}

The study's results emphasize the importance of reducing public debt in both the medium and the long-term; given the negative impact of excessive debt on growth, thus the study recommends the following policy implications:

1) Definitely the major contributor to Jordan's public debt is the persistent budget deficit. Thus, the austerity measures and fiscal discipline should be enforced by the government; the fiscal management should be enhanced through implementing fiscal reforms aiming at controlling the government expenditures along with enhancing the collection of tax revenues and modernizing public administration procedures that would contribute to the reduction of the budget deficit to reasonable levels. However, the implemented austerity measures and fiscal discipline should be carefully planned to minimize the potential negative effect on growth. Thus it should be implemented along with fiscal reforms intended for increasing employment and boosting Jordan's growth potential.

2) The domestic debt management strategy should be revised thoroughly to control the increased stock of domestic debt that would further depress capital accumulation and deter economic growth by means of higher long-term interest rates and higher future distortionary taxes. Furthermore, the increased domestic debt reduces the government capacity to perform the required counter-cyclical fiscal policies. Moreover, the government should revise the external debt management strategy and exert more efforts towards restructuring the external public debt stock that involves rescheduling of principal payments and interest payments relief, debt swaps, and debt forgiveness. However, it should diversify its external borrowings by reducing the dependency on one particular debt instrument or currency in order to minimize the potential risk related to the increased external borrowings.

\section{References}

[1] World Bank (2016). Jordan Economic Monitor: Reviving a Slowing Economy, third quarter. A quarterly Publication of Jordan Country Unit. Washington, D. C.: The World Bank. 
[2] Kumar, M. and Woo, J. (2010). Public Debt and Growth. IMF Working Paper 10/174, Washington, D. C.: IMF.

[3] Tomaselli, M. (2018). Economic Growth and Public Debt: Beyond Debt-Thresholds. Theoretical and Empirical Issues. Unpublished Doctoral Dissertation, University of Trento, Italy.

[4] Aghion, P. and Kharroubi, E. (2007). Cyclical Macro Policy and Industry Growth: The Effect of Countercyclical Fiscal Policy. Harvard University Working Paper.

[5] Woo, J. (2009). Why Do More Polarized Countries Run More Procyclical Fiscal Policy? Review of Economics and Statistics, 91 (4), 850-870.

[6] Hausmann, R. and Panizza, U. (2011). Redemption or Abstinence? Original Sin, Currency Mismatches and Counter Cyclical Policies in the New Millennium. Journal of Globalization and Development, 2 (1), 1-35.

[7] DeGrauwe, P. (2011). The Governance of a Fragile Eurozone. Working Document No. 346, CEPS, May.

[8] Panizza, U. (2008). Domestic and External Public Debt in Developing Countries. United Nations Conference on Trade and Development (UNCTAD) Discussion Papers 188.

[9] Al-Adayleh, R., Al-Amro, H., \& Al-Gralleh, H. (2015). The Structure of Public Debt in Jordan and its Impact on Economic Growth (1980-2012). Dirasat: Administrative Sciences, 42 (2), 515-530.

[10] Alshyab, N. (2016). Domestic versus External Public Debt in Jordan: An Empirical Investigation. Journal of Economic Sciences, 3 (1), 81-98. https://doi.org/10.12816/0029858

[11] Reinhart, C. Rogoff, K. and Savastano, M. (2003). Debt Intolerance. Brookings Papers on Economic Activity, 34 (1), $1-74$.

[12] Goldstein, M. and Turner, P. (2004). Controlling Currency Mismatches in Emerging Markets, Peterson Institute for International Economics, Washington DC.

[13] Agénor, P. R. and Montiel, P. (1996). Development Macroeconomics. Princeton, New Jersey: Princeton University Press.

[14] Serven, L. (1997). Uncertainty, Instability, and Irreversible Investment: Theory, Evidence and Lessons for Africa. World Bank Policy Research, Working Paper No. 1722, Washington, D. C., World Bank.

[15] Rodrik, D. (2008). The Real Exchange Rate and Economic Growth. Brookings Papers on Economic Activity, 39 (2), 365439.

[16] Presbitero, A. (2012). Domestic debt in low income countries. Economics Bulletin, 32 (2), 1099-1112.

[17] Abbas, A. S. M. and Christensen, J. (2010). The Role of domestic debt markets in economic growth: an empirical investigation for low-income countries and emerging markets. IMF Staff Papers 57 (1), 209-255.

[18] Mehrotra, A. N. Miyajima, K. and Villar, A. (2012). Developments of domestic government bond markets in EMEs and their implications. Fiscal Policy, Public Debt and Monetary Policy in Emerging Market Economies, 67, 31-50. Bank for International Settlements.

[19] Bacchiocchi, E. and Missale, A. (2012). Multilateral indexed loans and debt sustainability. UNCTAD Discussion Papers No. 209.

[20] Reinhart, C. M. and Rogoff, K. S. (2011). The forgotten history of domestic debt. The Economic Journal, 121 (552), 319-350.

[21] Checherita-Westphal, C. and Rother, P. (2012). The impact of high government debt on economic growth and its channels: an empirical investigation for the euro area. European Economic Review, 56 (7): 1392-1405.

[22] Were, M. (2001). The impact of external debt on economic growth and privateinvestments in Kenya: An empirical assessment, Working Paper, Kenya Institute for Public Policy Research and Analysis, Nairobi.

[23] Schclarek, A. (2004). Debt and economic growth in developing and industrial countries. Working Paper 2005, 34, Department of Economics, Lund University.

[24] Arnone, M., Bandiera, L., and Presbitero, A. F. (2005). External Debt Sustainability: Theory and Empirical Evidence. Catholic University of Piacenza Economics Working paper 33, 1-47.

[25] Adofu, I. and Abula, M. (2010). Domestic Debt and the Nigerian Economy. Current Research Journal of Economic Theory, Vol. 2 (1), 22-26.

[26] Umaru, A., Hamidu, A. A., and Musa, S. (2013). External debt and domestic debt impact on the growth of the Nigerian economy. International Journal Educational Research, 1 (2), $70-85$.

[27] Almeida, R. and Fernandes, A. (2008), Openness and technological innovations in developing countries: evidence from firm-level surveys. The Journal of Development Studies, 44 (5), 701-727.

[28] Bond, E. W. Jones, R. W. and Ping, W. (2005), Economic takeoffs in a dynamic process of globalization. Review of International Economics, 13 (1), 1-19.

[29] Reinhart, C. M. and Rogoff, K. S. (2009). The Aftermath of Financial Crisis. American Economic Review, 99 (2), 466472.

[30] Reinhart, C. M. and Rogoff, K. S. (2010). Growth in a Time of Debt. American Economic Review, 100 (2), 573-578.

[31] Eberhardt, M. and Presbitero, A. F. (2015). Public debt and growth: Heterogeneity and non-linearity. Journal of International Economics, 97 (1), 45-58.

[32] Swamy, V. (2015). Government Debt and Economic Growth Decomposing the Cause and Effect Relationship. Institute of Economic Growth, Delhi, Delhi, Online at http://mpra.ub.unimuenchen.de/64105/ MPRA Paper No. 64105.

[33] Shrestha, M. B. and Bhatta, G. R. (2018). Selecting appropriate methodological framework for time series data analysis. The Journal of Finance and Data Science, 4, 71-89.

[34] Wei, W. S. (2006). Time series analysis: Univariate and multivariate. Boston: Pearson.

[35] Philips, P. C. B. and Hansen, B. E. (1990). Statistical Inference in Instrumental Variables Regressions with I (1) Processes. The Review of Economic Studies, 57, 99-125.

[36] Philips, P. C. B. (1995). Fully modified least squares and vector autoregression. Econometrica, 63 (5), 1023-1078. 